\title{
High prevalence of Sarcocystis funereus sp. nov. (Apicomplexa, Sarcocystidae) in offspring of Tengmalm's owls Aegolius funereus (Aves, Strigidae)
}

Ondrej Máca

State Veterinary Institute Prague

Marek Kouba

Czech University of Life Sciences Prague: Ceska Zemedelska Univerzita v Praze

Erkki Korpimäki

University of Turku, Section of Ecology

David González-Solis ( $\sim$ dgonzale@ecosur.mx )

El Colegio de la Frontera Sur https://orcid.org/0000-0001-7765-2865

\section{Research}

Keywords: Birds, Europe, Intestinal mucosa, Molecular characterization, Ooocysts and sporocysts, Phylogeny

Posted Date: June 14th, 2021

DOI: https://doi.org/10.21203/rs.3.rs-608665/v1

License: (c) (i) This work is licensed under a Creative Commons Attribution 4.0 International License.

Read Full License 


\section{Abstract \\ Background}

Birds act as intermediate or definitive hosts of cyst-forming coccidia parasites of the genus Sarcocystis Lankester, 1882. However, the spectrum of species of Sarcocystis in birds and the role of the latter in the transmission of coccidia are still incomplete for many avian species including Tengmalm's owl Aegolius funereus (Linnaeus, 1758). During a research of Tengmalm's owls in Finland some fledglings were found dead and subsequently parasitologically examined. Therefore, this study is focused on the morphological and molecular description of a new Sarcocystis species found in the intestine of the Tengmalm's owl and its possible role as definitive host.

\section{Methods}

Eleven fledgling owls from the Kauhava region of west-central Finland were found dead and subsequently were submitted for necropsy, parasitologically examined through flotation-centrifugation coprological technique for the presence of oocysts/sporocysts of genus Sarcocystis by light microscopy. Wet mounts were used for the examination of muscle samples (breast, legs, heart). Polymerase chain reaction and nested-PCR were carried out by using primers for $18 S$ rRNA, 28S rRNA, ITS1 region and cox 1 genes.

\section{Results}

All eleven examined birds were parasitized by numerous sporocysts and oocysts in the intestinal mucosa scrapings (prevalence 100\%). Sporulated oocysts and sporocysts measured $16.34-16.96 \times 11.47-$ $12.09 \mu \mathrm{m}$ and $11.85-13.52 \times 7.77-9.25 \mu \mathrm{m}$, respectively. Skeletal and heart muscles were negative for sarcocysts. The phylogenetic analysis revealed that Sarcocystis funereus sp. nov. is closely related to Sarcocystis strixi from the barred owl (Strix varia Barton, 1799) from the USA and Sarcocystis sp. isolate 5 from the European shrew (Sorex araneus Linnaeus, 1758) from the Czech Republic, but a valid species.

\section{Conclusions}

This work provided the first and the most comprehensive record on Sarcocystis from owls obtained in Finland, thus highlighting the importance of molecular data in the species identification.

\section{Background}

Cyst-forming coccidia parasites of the genus Sarcocystis Lankester, 1882 can infect a wide variety of vertebrates, including birds, which could act as definitive and intermediate hosts in the life cycle of these parasites. However, the spectrum of species of Sarcocystis in birds and the role of the latter in the 
transmission of coccidia are still incomplete for many avian species including Tengmalm's owl Aegolius funereus (Linnaeus, 1758). This species is a small nocturnal cavity-nesting owl living in coniferous forests in the boreal zone and in alpine forests further south in the Holarctic region [1, 2]. It feeds mainly on small mammals, among which voles of the genera Myodes Pallas, 1779 (=Clethrionomys Tilesius, 1850) and Microtus Schrank, 1798 are their main preys, while shrews of the genus Sorex and small forest birds are their most important alternative prey items [3 - 5].

To date, relatively few studies have been conducted with the Sarcocystis species in A. funereus in wild; in fact, only Wiesner [6], in a scientific meeting, reported sporocysts of Sarcocystis sp. in the Tengmalm's owl, which were experimentally developed in the bank vole Myodes glareolus (= Clethrionomys glareolus) Schreber, 1780. Whereas Zuo et al. [7] and Zuo and Yang [8] were unsuccessful in experimentally infecting A. funereus with Sarcocystis sinensis Zuo, Zhang et Yie, 1990 from China.

During radio-telemetry research of Tengmalm's owls in Finland, where decreasing densities of main prey (voles) occurred, some fledglings were found dead and subsequently parasitologically examined. Since this owl species has practically no records of species of Sarcocystis and the role of owl in the life cycle of parasite is partially known, this study is focused on the morphological and molecular description of a new Sarcocystis species found in the intestine of the Tengmalm's owl and its possible role as definitive host.

\section{Methods}

The carcasses of 11 specimens ( $29-47$ days old from hatching, $98-136 \mathrm{~g}$ in weight) from 7 different nests (10 died due to starvation and infection, 1 per marten Martes martes Linnaeus, 1758 predation) (MK and EK unpublished data) were examined in this study. They were collected in the Kauhava region of west-central Finland $\left(63^{\circ} \mathrm{N}, 23^{\circ} \mathrm{E}\right)$ during a radio-tracking study of Tengmalm's owl fledglings during the post-fledging dependence period in 2019. The study area is located $30-120 \mathrm{~m}$ above sea level and mostly covered by forest [for detailed description of the study area (see $[4,9,10])$. Aerial distances $(n=$ 21) between involved nest boxes from which the fledglings originated and later subjected to necropsy were $19.2 \pm 9.3 \mathrm{~km}$ on average (range $3.8-38.7 \mathrm{~km}$ ).

Necropsies were carried out in the State Veterinary Institute (SVI) Prague, Czech Republic, where the intestinal content and muscular samples (breast, legs, heart) of thawed birds were parasitologically examined in wet mouth using water or glycerine for orientation purposes. After parasite finding, intestinal mucosa scrapings were used for flotation-centrifugation coprological method under light microscopy for the final evaluation and presence of oocysts/sporocysts using a Leica DMLB optical microscope with a Leica DFC420 digital camera (Leica Microsystems, Wetzlar, Germany), and isolation to Eppendorf tubes for DNA extraction. All measurements are given in micrometres, unless otherwise mentioned.

Genomic DNA was extracted by glass bead disruption from 22 isolates (two from each owl) of oocysts/sporocysts using the QIAamp ${ }^{\circledR}$ Fast DNA Stool Mini Kit (Qiagen, Hilden, Germany) according to the manufacturer's recommendations. DNA was stored at $-20^{\circ} \mathrm{C}$ until further use. 
Polymerase chain reaction (PCR) and nested-PCR were carried out by using primers for $18 S$ rRNA (ERIB1/A2R, A1F/S2r, A2F/Primer BSarc and Fext/Rext, Fint/Rint, respectively) [11 - 15], 28S rRNA (KL_P1R/KL_P1F) [16], ITS1 region (ITS-F/ITS-R) [16] and cox1 genes (SF1/SR10) [17, 18]. The PCR mixture (20 $\mu$ l of reaction mixture and $5 \mu$ of DNA extract) comprising of GoTaq® $\mathrm{G} 2$ Green Master Mix (Promega, Madison, Wisconsin, USA), $0.4 \mu \mathrm{M}$ of each primer, DNA template and nuclease-free water to obtain a final volume of $25 \mu \mathrm{l}$. PCR conditions consisted of initial denaturation at $95^{\circ} \mathrm{C}$ for $5 \mathrm{~min}$, followed by 35 cycles of $95^{\circ} \mathrm{C}$ for $30 \mathrm{~s}, 52-60^{\circ} \mathrm{C}$ for $30 \mathrm{~s}, 72^{\circ} \mathrm{C}$ for $1 \mathrm{~min}$, and then a final extension step at $72^{\circ} \mathrm{C}$ for $10 \mathrm{~min}$. The amplification products were resolved on $1.5 \%$ agarose gels and visualized by ethidium bromide staining. The PCR products were purified using the ExoSAP-IT ${ }^{T M}$ Express PCR Product Cleanup Reagent kit (Thermo Fisher Scientific) according to the manufacturer's protocol. Purified PCR products were directly sequenced in both forward and reverse directions using the same primers as for PCR through the commercial company Eurofins Genomics (Ebersberg, Germany). Nucleotide sequences of $18 S$ rRNA, 28S rRNA, ITS1 and cox 1 loci of $S$. funereus sp. nov. have been deposited in GenBank under the accession numbers MW349706, MW349707, MW373964, MW489293, respectively. Sequences from both forward and reverse strands were assembled and manually edited using FinchTV software (Geospiza Inc., Seattle, Washington) followed by BLAST (Basic Local Alignment Search Tool) program at the NCBI (National Center for Biotechnology Information) server, searches were conducted on obtained sequences for genus/species identification. Sequence chromatograms obtained in this study were aligned using MAFFT software version 7 [19].

Phylogenetic trees for all datasets were generated form nucleotide sequences of the selected Sarcocystis species using the MEGA X [20] and reconstructed by using the Neighbor-Joining (NJ) and Maximum Likelihood (ML) methods. A NJ phylogenetic tree for 18 S rRNA gene (dataset with 25 nucleotide sequences with a total of 1644 aligned nucleotide positions) was computed according to the Tamura-Nei model with a gamma distribution $(\mathrm{TN} 93+\mathrm{G})$. Other phylogenetic trees were generated using $\mathrm{ML}$ analyses based on the Kimura 2-parameter model with a gamma distribution rate and a proportion of invariant sites $(K 2+G+I)$ for 28 S rRNA gene (25 sequences with 1442 positions); for cox 1 gene (18 sequences with 1013 positions) the Hasegawa-Kishino-Yano model with a gamma distribution (HKY + G) was used, while the Tamura-Nei model with a gamma distribution rate and a proportion of invariant sites (TN93 + G + I) was used for ITS1 region (24 sequences with 1426 positions). All four phylogenetic trees were rooted using Toxoplasma gondii sequence. Consensus trees were obtained after bootstrap analysis with 1000 replications.

\section{Results}

All intestinal samples of the eleven examined owls were positive to Sarcocystis funereus sp. nov. (prevalence: 100\%), whereas samples of muscular tissues were negative. Oocysts/sporocysts were described as follows:

Family Sarcocystidae Poche, 1913 
Sarcocystis funereus sp. nov. (Fig. 1)

Description: thin-walled sporulated oocysts (Fig. 1a), $16.34-16.96 \times 11.47-12.09(n=5)$ and sporocysts (Fig. 1b) were $11.85-13.52 \times 7.77-9.25(n=35)$.

\section{Taxonomic summary}

Definitive host: Tengmalm's owl Aegolius funereus Linnaeus, 1758 (Strigiformes: Strigidae).

Intermediate host: Unknown.

Distribution: Kauhava region, west-central Finland (approx. $63^{\circ} \mathrm{N}, 23^{\circ} \mathrm{E}$ ).

Site of infection: Small intestine.

Prevalence: $100 \%$ (11 owls examined/11 infected).

\section{Deposited material}

Symbiotype (oocysts/sporocysts in 2.5\% potassium dichromate), and genomic DNA in Eppendorf tube were stored at SVI Prague. GenBank sequences MW349706 (18S rRNA gene), MW349707 (28S rRNA gene), MW373964 (ITS1 region), MW489293 (cox1 gene).

ZooBank registration: To comply with the regulations set out in article 8.5 of the amended 2012 version of the International Code of Zoological Nomenclature [21], details of the new species have been submitted to ZooBank. The Life Science Identifier (LSID) for Sarcocystis funereus sp. nov. is urn:

\section{Etymology}

The specific epithet is derived from the species name of its definitive host, i.e., funereus.

Genetic sequences of 20 Sarcocystis isolates (10 birds) were obtained for the $18 S$ rRNA, 28S rRNA, ITS1 and cox 1 loci. All obtained 18 S rRNA sequences were identical; therefore, only one of $1773 \mathrm{bp}$ was submitted to GenBank (MW349706). It shared a 99.69\% similarity with an Sarcocystis sp. isolate 5 (as named in GenBank) (1594 bp) (AF513487) from the European shrew (Sorex araneus Linnaeus, 1758) from the Czech Republic, 99.61\% with S. strixi Verma, von Dohlen, Mowery, Scott, Cerqueira-Cézar, Rosenthal, Dubey et Lindsay, 2017 (MF162315) in the barred owl (Strix varia Barton, 1799) from USA, and 99.55\% with S. corvusi Prakas, Kutkiené, Butkauskas, Sruoga et Žalakevičius, 2013 (JN256117) in the jackdaw (Corvus monedula [Linnaeus, 1758]) from Lithuania, S. halieti Gjerde, Vikøren et Hamnes, 2018 (MH130211, MF946587) in the great cormorant (Phalacrocorax carbo [Linnaeus, 1758]) from Lithuania, and the white-tailed sea eagle (Haliaeetus albicilla [Linnaeus, 1758]) from Norway. The 28S rRNA sequence (MW349707) was 1509 bp and shared 97.59\% genetic similarity with S. strixi (MF162316) and S. lari Prakas, Kutkiené, Butkaukas, Sruoga et Žalakevičius, 2014 (MF946611) in the white-tailed sea eagle from Norway, whereas it shared $97.49 \%$ similarity with S. Iutrae Gjerde et Josefsen, 2015 
(KM657771) in the Eurasian otter (Lutra lutra [Linnaeus, 1758]) from Norway. Sequence analyses of the cox1 gene (MW489293) was 1060 bp and showed a high similarity (99.52\%) with S. strixi (MF162317), 99.43\% with S. lutrae (KM657808) and 99.42\% with S. Iari (MF596283, MF946584) from the great blackbacked gull (Larus marinus [Linnaeus, 1758]) from Lithuania and the white-tailed sea eagle from Norway. The ITS1 region sequence was 1294 bp (MW373964), 89.57\% similar to S. halieti (MF946596) and $89.52 \%$ similar to S. Iutrae (MG372109) in L. lutra from the Czech Republic.

The phylogenetic trees showed different topologies and relationships between the new species with its congeners according to the availability of sequences. Phylogenetic trees based on $18 S$ rRNA, 28S rRNA and cox 1 genes showed a clade formed by the new species and S. strixi, as well as Sarcocystis sp. 5 (in the case of $18 S$ rRNA) (Fig. 2a, b, d), while tree of ITS1 region showed $S$. funereus sp. nov. lonely in a single clade since the ITS1 sequence of $S$. strixi was not available, although the new species formed a group with other Sarcocystis spp. (Fig. 2c).

\section{Discussion}

The first published finding and description of the oocysts/sporocysts of Sarcocystis sp. in the Tengmalm's owl was made by Wiesner [6] in Europe. Other Sarcocystis using owls as definitive hosts are: S. espinosai (Espinosa, Sterner, Blixt et Cawthorn, 1988) Odening, 1997 in the northern saw-whet owl Aegolius acadicus (Gmelin, 1788) from the USA [22]; S. dispersa Černá et Sénaud, 1977 in the long-eared owl Asio otus (Linnaeus, 1758), barn owl Tyto alba (Scopoli, 1769), masked owl T. novaehollandiae (Stephens, 1826) and Ninox novaeseelandie (Gmelin, 1788) in the Czech Republic and Australia [23 - 27]; S. rauschorum Cawthorn, Gajadhar et Brooks, 1984 in the snowy owl Bubo scandiacus (reported as Nyctea scandiaca) (Linnaeus, 1758) from Canada [27]; S. scotti Levine et Tadros, 1980 (this species is considered invalid by [28]) and S. sebeki (Tadros et Laarman, 1976) Levine, 1978 both in the tawny owl Strix aluco Linnaeus, 1758 from Europe [29, 30]; and S. strixi in the barred owl Strix varia from USA [31]. Hoberg et al. [32] reported a coccidian (resembling Frenkelia or Sarcocystis) in the northern spotted owl Strix occidentalis caurina Xantus de Vesey, 1860 from the USA, although the proper identity of the parasite was undetermined. There also are reports of owls acting as intermediate hosts for $S$. falcatula Stiles, 1983 in the great-horned owl Bubo virginianus (Gmelin, 1788) from the USA [33] and S. otus Krone, Rudolphi et Jakob, 2000 (invalid species according to [28]) in As. otus from Germany [34]. Most of these were solely morphologically studied, while only sporocysts of $S$. dispersa in Tyto alba (18S rRNA) [35] and S. strixi (18S rRNA, 28S rRNA and cox1) [31] were morphological and molecularly characterized.

The size of fully sporulated sporocysts of Sarcocystis espinosai, S. rauschorum, S. sebeki and S. strixi are within the range for those of the new species $(9.5-14.0 \times 8.0-12.0 \mu \mathrm{m}, 9.6-14.0 \times 7.0-10.0 \mu \mathrm{m}$ and $11.2-13.7 \times 8.8-10.9 \mu \mathrm{m}$ vs $11.85-13.52 \times 7.77-9.25 \mu \mathrm{m})$, and partially with the sporocysts and oocysts of Sarcocystis sp. in S. o. caurina, S. dispersa and S. sebeki $(11.0-12.0 \times 5.0-6.0 \mu \mathrm{m}, 11-14 \times$ $8-11 \mu \mathrm{m}$ and $10.0 \times 14.0 \mu \mathrm{m}$ vs $11.85-13.52 \times 7.77-9.25 \mu \mathrm{m} ; 12.4-15.5 \times 9.3-12.4$ and $17-20 \times$ $10-13 \mu \mathrm{m}$ vs $16.34-16.96 \times 11.47-12.09)$. Since the morphological parameters of oocysts/sporocysts are insufficient to distinguish species, the comparison of these Sarcocystis with the new species is 
unreliable. The sporocysts and oocysts of Sarcocystis sp. of Wiesner [6] were not described, so it is impossible to say if it belongs to $S$. funereus sp. nov., although they could be conspecific.

On the other hand, of those species molecularly characterized, as S. dispersa (18S rRNA) and S. strixi (18S rRNA, 28S rRNA and cox 1), the first formed a different clade than that of $S$. funereus sp. nov., while the second grouped together with the new species in the three genes. Apparently, S. strixi and Sarcocystis sp. 5 are closely related (sister) to $S$. funereus sp. nov., but with genetic differences to be still considered as separated species. The ITS1 region is more sensitive to the genetic differences among Sarcocystis species (see [36 - 38]), while the 18S rRNA gene is now considered of limited taxonomic help [28]. Unfortunately, ITS1 region was not used previously in S. dispersa nor S. strixi, thus making their comparison with the new species limited. This is the first time that the ITS1 region was sequenced for a Sarcocystis from owls as definitive hosts and clearly revealed the differences among species.

The intermediate host of $S$. funereus sp. nov. is unknown, but apparently rodents (different species of mice and voles inhabiting the study area) (see $[4,39]$ ) play that important role. Experimentally, Wiesner [6] observed that the bank vole $M$. glareolus acts as intermediate host and it could also be the potential host for the new species, while the northern saw-whet owl A. acadicus, a congeneric owl species from the USA, used the deer mice (Peromyscus maniculatus) (see [22]). According to Mikkola [1], König and Weick [2], there are more than 47 mammalian and 66 bird species used as preys by owls in Europe, which could act as intermediate hosts for $S$. funereus sp. nov. The most common small mammals used as prey by the Tengmalm's owl are the bank vole, field vole (Microtus agrestis [Linnaeus, 1761]), sibling vole (Microtus levis [syn. M. rossiaemeridionalis] Miller, 1908) and harvest mouse (Micromys minutus [Pallas, 1771]); less commonly are shrews (genus Sorex) $[4,39]$. In the study area, the main preys of Tengmalm's owl are bank voles, field voles and sibling voles, whose abundances regularly fluctuate in high-amplitude (100 200 -fold) three-year cycle [40 - 43]. Accordingly, the abundances of individual vole species vary strongly. The overall prey abundance could be $0.2-13.1$ and $0.6-28.2$ vole individuals per 100 trap-nights as revealed by regular long-term snap-trapping in the study area during spring and autumn, respectively, thus differing up to 65 -fold times between different years/phases of the vole cycle $[4,10,42]$.

It has been mentioned that species of Sarcocystis are more specific to their intermediate than definitive hosts, especially those using rodents as intermediate hosts (see [28]). In the case of M. glareolus, it has been found as intermediate host of several types and unnamed species of Sarcocystis from the Czech Republic [44], Baltic region [45] and Lithuania [46], as well as of S. clethrionomyelaphis Matuschka, 1986 in Germany, which uses canids, mustelids, snakes or birds of prey as definitive hosts (see [47, 48]). One of the forms from Lithuania showed similar features (dense hair-like projections on cyst wall) than that of Sarcocystis sp. described by Wiesner [6] (see [46]), thus corroborating the role of bank vole in the life cycle of the parasite.

The cause of death of Tengmalm's owls was undetermined, but the occurrence of Sarcocystis in these birds should be monitored, since other taxa of this genus ( $S$. falcatula, Sarcocystis sp. isolate from 
chicken) have been reported as causing encephalitis in free-ranging great owls ( $B$. virginianus) and meningoencephalitis in chickens, respectively (see $[33,49])$.

In the last decades, the integrative taxonomy by using morphological features and molecular analysis has uncovered the huge diversity of species in various groups of organisms, including protists [28]. Additionally, it particularly improved the recognition of the specificity of Sarcocystis in their intermediate and definitive hosts around the world. According to the high infection prevalence of the present study, the Tengmalm's owl acted as natural definitive host for $S$. funereus sp. nov., thus representing the first host record in A. funereus and the nineth owl species with a Sarcocystis species. Apparently, S. funereus sp. nov. is specific to $A$. funereus, since the latter was experimentally infected with $S$. sinensis and sporocysts and oocysts were no found after some days of infection (see [8]). However, birds of prey might be infected by more than one Sarcocystis species, as $S$. halieti and $S$. lari in the white-tailed sea eagle ( $H$. albicilla) (see [15]); therefore, more Tengmalm's owls, other owl species and birds of prey should be examined to determine the presence of other species or forms.

Tengmalm's owls are nomadic and the natal dispersal movements of those juveniles hatched in Finland could extend more than $1000 \mathrm{~km}$ [50,51], while adult females show long distance breeding dispersal up to $>600 \mathrm{~km}$ in Finland $[4,50]$ and adult males are usually resident after their first breeding attempt [4].

They can also move over long distances and are widely distributed in North and Central Europe including the Italian Alps and Pyrenees in North Spain [1]. Therefore, it is highly probable that Tengmalm's owls could spread $S$. funereus sp. nov. out of Finland to various other locations within their distribution range. For instance, during a long-term study of Tengmalm's owl in the Czech Republic (years 2010-12 and 2015) a prevalence of $40 \%$ was found for a Sarcocystis sp. in 10 fledglings $[52,53]$. Thus, these parasites seem to be present in that country, although the species identification should be confirmed to determine the real distribution of $S$. funereus sp. nov. However, Svobodová [54] examined two Tengmalm's owls in the Czech Republic, which were negative to the presence of oocysts/sporocysts of Sarcocystis.

If we considered that family Strigidae comprises 223 species of owls reported around the world, more studies are needed to elucidate the parasite fauna and involvement of these birds in the life cycles of parasites. Thus, new findings will help in increasing the knowledge about this interesting group of predators, as well as their role as predators of rodents, which also act as intermediate hosts of several Sarcocystis.

\section{Conclusions}

This work provided the first and the most comprehensive record on Sarcocystis from owls, thus highlighting the importance of molecular data in the species identification. This work contributes to the better understanding of species diversity and current taxonomic status of the new species within the genus Sarcocystis. Further works including examinations of owl populations and particularly their preys in Finland, the Czech Republic and worldwide are required to elucidate the life cycle of the parasite. 


\section{Abbreviations}

bp: base pairs

cox1: cytochrome c oxidase subunit 1

DNA: deoxyribonucleic acid

ITS1: internal transcribed spacer 1

ML: Maximum likelihood

NJ: Neighbor-joining

PCR: polymerase chain reaction

rRNA: ribosomal ribonucleic acid

sp. nov: new species

\section{Declarations}

\section{Acknowledgements}

The authors thank to all colleagues from Laboratory of Parasitology (SVI Prague), especially E. Dubská. Thank are also to T. Bušina and K. Hongisto for their great help during the field work in Kauhava study area, as well as 0 . Doskočil for making the graphical abstract. This research was performed within the Centre for Infectious Animal Diseases. Succumbed fledglings of Tengmalm's owls were collected, preserved and transported to State Veterinary Institute Prague, Czech Republic under the permission obtained from the Centre for Economic Development, Transport and the Environment in Southwest Finland (permit number VARELY/5933/2019 to Erkki Korpimäki).

\section{Ethics approval and consent to participate}

Not applicable.

\section{Consent for publication}

Not applicable.

\section{Availability of data and materials}

The sequences generated in the present study were submitted to the GenBank database under the accession numbers MW349706, MW349707, MW373964, MW489293. 
The authors declare that they have no competing interests.

\section{Funding}

Open access funding was provided by the Faculty of Agrobiology, Food and Natural Resources, Czech University of Life Sciences Prague. The research project of owls in the Kauhava region was financially supported by the grant provided by the Regional Fund of the South Ostrobothnia of the Finnish Cultural Foundation.

\section{Authors' contributions}

OM conceived and designed the study, MK and EK conducted field research/collection, OM performed laboratory analyses and analyzed data, OM, DGS, wrote the main manuscript. All authors read and approved the final manuscript.

\section{References}

1. Mikkola H. Owls of Europe. Calton: T \& AD Poyser; 1983.

2. König C, Weick F. Owls of the world. Second edition. New Haven and London, Yale University Press; 2008.

3. Korpimäki E. On the ecology and biology of Tengmalm's owl (Aegolius funereus) in southern Ostrobothnia and Soumenselkä, western Finland. Acta Univer Ouluensis, Ser A, Scient Rer Nat 118. 1981;13:1-84.

4. Korpimäki E, Hakkarainen $\mathrm{H}$. The Boreal owl: ecology, behaviour and conservation of a forestdwelling predator. Cambridge: Cambridge University Press; 2012.

5. Kouba M, Bartoš L, Šindelář J, Štastný K. Alloparental care and adoption in Tengmalm's owl (Aegolius funereus). J Ornithol. 2017;158:185-91.

6. Wiesner J. A new sarcosporidian species of Clethrionomys glareolus inhabiting the owl Aegolius funereus as definitive host. J Protozool. 1980;27:72A.

7. Zuo Y-X, Zhang YH, Yie B. Sarcocystis sinensis sp. nov. from water buffalo. Abstracts of the Fifty Symposium of the Chinese Society for Protozoology; 1990. p. 82-3.

8. Zuo Y-X, Yang Z-Q. The validity of Sarcocystis sinensis. Zool Res. 2015;36:109-11.

9. Korpimäki E. Highlights from a long-term study of Tengmalm's owls: cyclic fluctuations in vole abundance govern mating systems, population dynamics and demography. Brit Birds. 2020;113:316-33.

10. Kouba M, Bartoš L, Bartošová J, Hongisto K, Korpimäki E. Interactive influences of fluctuations of main food resources and climate change on long-term population decline of Tengmalm's owls in the boreal forest. Sci Report. 2020;10:1-14.

11. Barta JR, Martin DS, Liberator PA, Dashkevicz M, Anderson JW, Feighner SD, Elbrecht A, Perkins Barrow A, Jenkins MC, Danforth HD, Ruff MD, Profous-Juchelka H. Phylogenetic relationships among 
eight Eimeria species infecting domestic fowl inferred using complete small subunit ribosomal DNA sequences. J Parasitol. 1997;83:262-71.

12. Fischer S, Odening K. Characterization of bovine Sarcocystis species by analysis of their $18 \mathrm{~S}$ ribosomal DNA sequences. J Parasitol. 1998;84:50-4.

13. Gjerde B. Morphological and molecular characteristics of four Sarcocystis spp. in Canadian moose (Alces alces), including Sarcocystis taeniata n. sp. Parasitol Res. 2014;113:1591-604.

14. Dubey JP, Sykes JE, Shelton GD, Sharp N, Verma SK, Calero-Bernal R, Viviano J, Sundar N, Khan A, Grigg ME. Sarcocystis caninum and Sarcocystis svanain. spp. (Apicomplexa: Sarcocystidae) associated with severe myositis and hepatitis in the domestic dog (Canis familiaris). J Eukaryot Microbiol 2015;62:307-17.

15. Gjerde B, Vikøren T, Hamnes IS. Molecular identification of Sarcocystis halietin. sp., Sarcocystis lari and Sarcocystis truncata in the intestine of a white-tailed sea eagle (Haliaeetus albicilla) in Norway. Int J Parasitol: Parasites Wildlife. 2018;7:1-11.

16. Kutkienè L, Prakas P, Sruoga A, Butkauskas D. The mallard duck (Anas platyrhynchos) as intermediate host for Sarcocystis wobeseri sp. nov. from the barnacle goose (Branta leucopsis). Parasitol Res. 2010;107:879-88.

17. Gjerde B. Phylogenetic relationships among Sarcocystis species in cervids, cattle and sheep inferred from the mitochondrial cytochrome c oxidase subunit I gene. Int J Parasitol. 2013;43:579-91.

18. Gjerde B. Sarcocystis species in red deer revisited: with a re-description of two known species as Sarcocystis elongata n. sp. and Sarcocystis truncata n. sp. based on mitochondrial cox 1 sequences. Parasitology. 2014;141:441-52.

19. Katoh K, Standley DM. MAFFT multiple sequence alignment software version 7. improvements in performance and usability. Mol Biol Evol. 2013;30:772-80.

20. Kumar S, Stecher G, Li M, Knyaz C, Tamura K. MEGA X: Molecular evolutionary genetics analysis across computing platforms. Mol Biol Evol. 2018;35:1547-9.

21. ICZN (International Commission on Zoological Nomenclature). Amendment of articles 8, 9, 10, 21 and 78 of the International Code of Zoological Nomenclature to expand and refine methods of publication. Bull Zool Nom. 2012;69:161-9.

22. Espinosa R, Sterner M, Blixt J, Cawthorn R. Description of a species of Sarcocystis (Apicomplexa: Sarcocystidae), a parasite of the northern saw-whet owl, Aegolius acadicus, and experimental transmission to deer mice Peromyscus maniculatus. Can J Zool. 1988;66:2118-21.

23. Černá Ž. Relationship of oocysts of Isospora buteonis from the barn-owl (Tyto alba) to muscle cysts of sarcosporidians from the house mouse (Mus musadus). Folia Parasitol. 1976;23:285.

24. Munday BL. A species of Sarcocystis using owls as definitive hosts. J Wildlife Dis. 1977;13:205-7.

25. Černá Ž, Kolařova I. \& Šulc P. Contribution to the problem of cyst-producing coccidians. Folia Parasitol. 1978;25:9-16. 
26. Munday BL, Hartley WJ, Harrigan KE, Presidente PJA, Obendorf DL. Sarcocystis and related organisms in Australian wildlife: II. Survey findings in birds, reptiles, amphibians and fish. J Wildlife Dis. $1979 ; 15: 57-73$.

27. Cawthorn RJ, Gajadhar AA, Brooks RJ. Description of Sarcocystis rauschorum sp. n. (Protozoa: Sarcocystidae) with experimental cyclic transmission between varying lemmings (Dicrostonyx richardsoni) and snowy owls (Nyctea scandiaca). Can J Zool. 1984;62:217-25.

28. Dubey JP, Calero-Bernal R, Rosenthal BM, Speer CA, Fayer R. Sarcocystosis of Animals and Humans. Boca Raton: CRC Press; 2016.

29. Levine ND. Recent advances in classification of Protozoa. In: Romberger JA, editor. Biosystematics in Agriculture (Beltsville Symposia in Agricultural Research, 2); 1978. p. 71-87.

30. Levine ND, Tadros W. Named species and hosts of Sarcocystis (Protozoa: Apicomplexa: Sarcocystidae). Syst Parasitol. 1980;2:41-59.

31. Verma SK, von Dohlen A, Mowery J, Scott D, Cerqueira-Cézar C, Rosenthal B, Dubey JP, Lindsay D. Sarcocystis strixi n. sp. from a barred owl (Strix varia) definitive host and interferon gamma gene knockout mice as experimental intermediate host. J Parasitol. 2017;103:768-77.

32. Hoberg EP, Cawthorn RJ, Hedstrom OR. Enteric coccidia (Apicomplexa) in the small intestine of the northern spotted owl (Strix occidentalis caurina). J Wildlife Dis. 1993;29:495-7.

33. Wünschmann A, Rejmanek D, Cruz-Martinez L, Barr BC. Sarcocystis falcatula - associated encephalitis in a free-ranging great horned owl (Bubo virginianus). J Vet Diagn Invest. 2009;21:2837.

34. Krone O, Rudolphi M, Jakob W. Protozoa in the breast muscle of raptors in Germany. Acta Protozool. 2000;39:35-42.

35. Doležel D, Koudela B, Jirků M, Hypša V, Oborník M, Votýpka J, Modrý D. Šlapeta J and Lukeš J. Phylogenetic analysis of Sarcocystis spp. of mammals and reptiles supports the coevolution of Sarcocystis spp. with their final hosts. Int J Parasitol. 1999;29:795-8.

36. Prakas P, Butkauskas D, Švažas S, Juozaitytė-Ngugu E, Stanevičius V. Morphologic and genetic identifcation of Sarcocystis fulicaen. sp. (Apicomplexa: Sarcocystidae) from the Eurasian coot (Fulica atra). J Wildlife Dis. 2018;54:765-71.

37. Pan J, Ma C, Huang Z, Ye Y, Zeng H, Deng S, Hu J, Tao J. Morphological and molecular characterization of Sarcocystis wenzeli in chickens (Gallus gallus) in China. Parasite Vector. 2020;13:512-8.

38. Máca O, González-Solís D. Sarcocystis cristata sp. nov. (Apicomplexa, Sarcocystidae) in the imported great blue turaco Corythaeola cristata (Aves, Musophagidae). Parasite Vector. 2021;14:1-7.

39. Korpimäki E. Diet of breeding Tengmalm's owls Aegolius funereus: long term changes and year to year variation under cyclic food conditions. Ornis Fennica. 1988;65:21-30.

40. Hanski I, Hansson L, Henttonen H. Specialist predators, generalist predators, and the microtine rodent cycle. J Anim Ecol. 1991;60:353-67. 
41. Huitu O, Norrdahl K, Korpimäki E. Landscape effects on temporal and spatial properties of vole population fluctuations. Oecologia. 2003;135:209-20.

42. Korpimäki E, Norrdahl K, Huitu O, Klemola T. Predator-induced synchrony in population oscillations of co-existing small mammal species. P Roy Soc B-Biol Sci. 2005;272:193-202.

43. Korpela K, Delgado M, Henttonen H, Korpimäki E, Koskela E, Ovaskainen O, Pietiäinen $\mathrm{H}$, Sundell J, Yoccoz NG, Huitu O. Non-linear effects of climate on boreal rodent dynamics: mild winters do not negate high-amplitude cycles. Global Change Biol. 2013;19:697-710.

44. Šebek Z. Parasitische Gewebeprotozoen der wildlebenden Kleinsäuger in der Tschechoslovakei. Folia Parasitol. 1975;22:111-24.

45. Arnastauskiené T, Grikieniené J. Infection of small mammals with sarcosporidians in the SouthEastern Baltic region. Ecology. 1993;2:47-56. (in Russian).

46. Grikienienè J, Mažeikytè R. Investigation of sarcosporidians (Sarcocystis) of small mammals in Kamasta Landscape Reserve and its surroundings. Acta Zool Lituanica. 2000;10:55-68.

47. Matuschka FR. Sarcocystis clethrionomyelaphis n. sp. from snakes of the genus Elaphe and different voles of the family Arvicolidae. J Parasitol. 1986;72:226-31.

48. Mehlhorn H, Matuschka FR. Ultrastructural studies of the development of Sarcocystis clethrionomyelaphis within its final and intermediate hosts. Protistologica. 1986;22:97-104.

49. Wilson TM, Sousa SK, Paludo GR, de Melo CB, Llano HA, Soares RM, Castro MB. An undescribed species of Sarcocystis associated with necrotizing meningoencephalitis in naturally infected backyard chickens in the Midwest of Brazil. Parasitol Int. 2020;76:102098.

50. Korpimäki E, Lagerström M, Saurola P. Field evidence for nomadism in Tengmalm's owl Aegolius funereus. Ornis Scand. 1987;18:1-4.

51. Saurola P. Natal dispersal distances of Finnish owls: results from ringing. In: Newton I, Kavanagh R, Olsen J, Taylor I, editors. Ecology and Conservation of Owls. Collingwood: CSIRO Publishing; 2002. pp. 42-55.

52. Kouba M, Bartoš L, Št'astný K. Differential movement patterns of juvenile Tengmalm's owls (Aegolius funereus) during the post-fledging dependence period in two years with contrasting prey abundance. PLoS One. 2013;8(7):e67034.

53. Kouba M, Bartoš L, Štastný K. Factors affecting vocalization in Tengmalm's owl (Aegolius funereus) fledglings during post-fledging dependence period: scramble competition or honest signalling of need? PLoS One. 2014;9(4):e95594.

54. Svobodová M. Heteroxenous coccidia of raptors and owls from the Czech and Slovak Republics. Buteo. 1997;9:35-42.

\section{Figures}




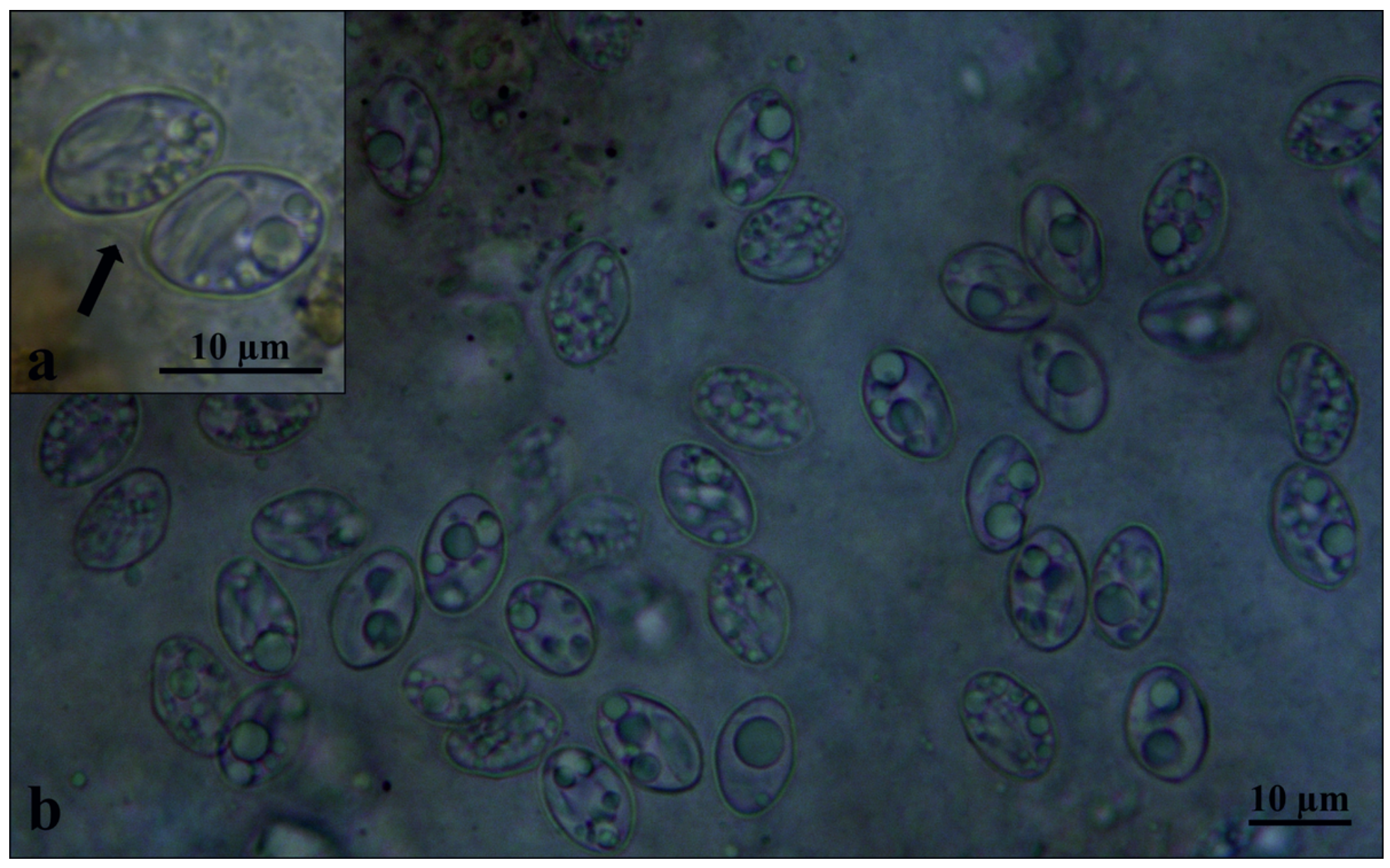

\section{Figure 1}

Sarcocystis funereus sp. nov. from Aegolius funereus, light micrographs of oocyst (a) and numerous sporocysts (b) in intestinal mucosa. Arrow indicates thin oocyst wall 

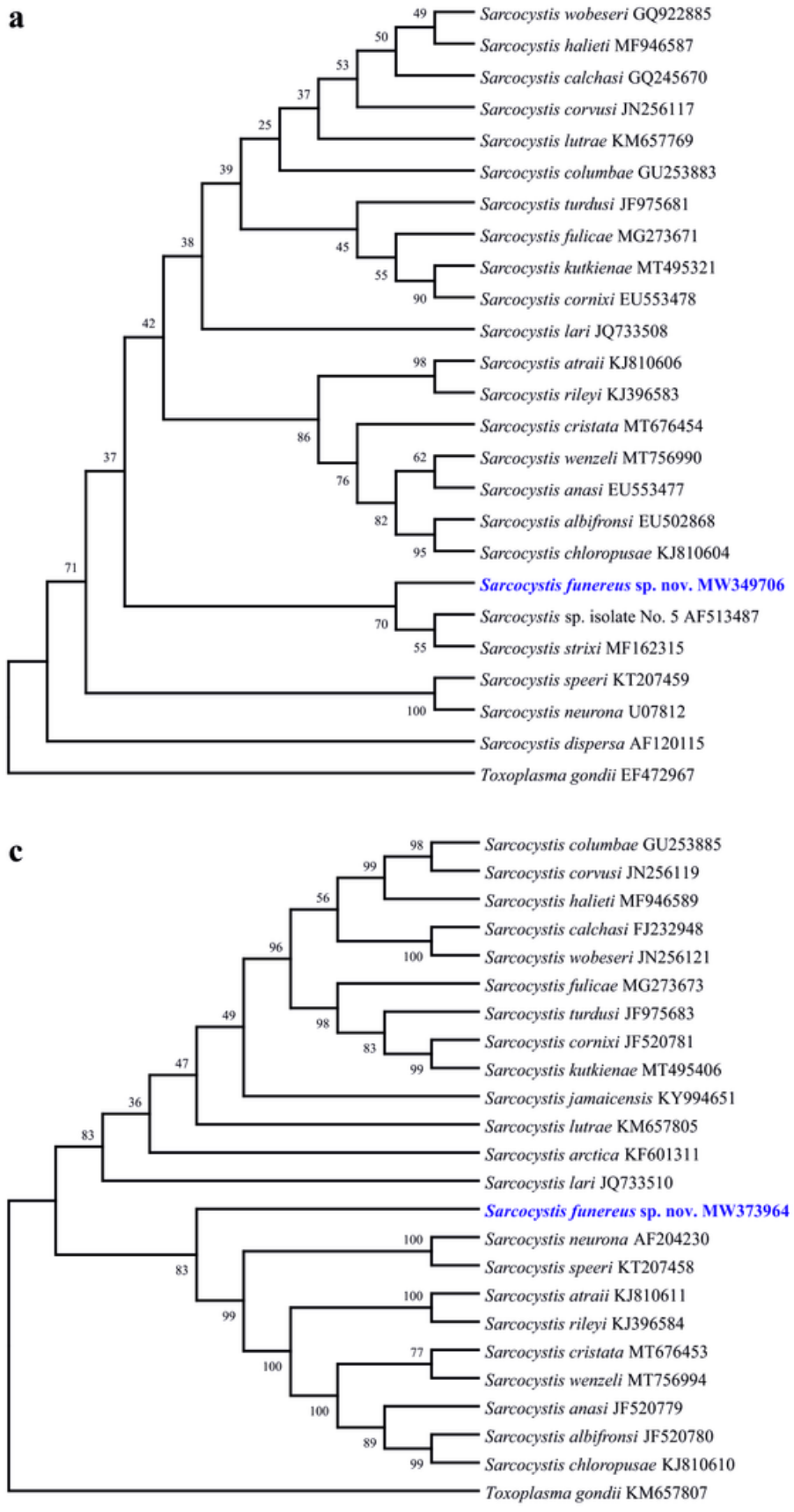

b
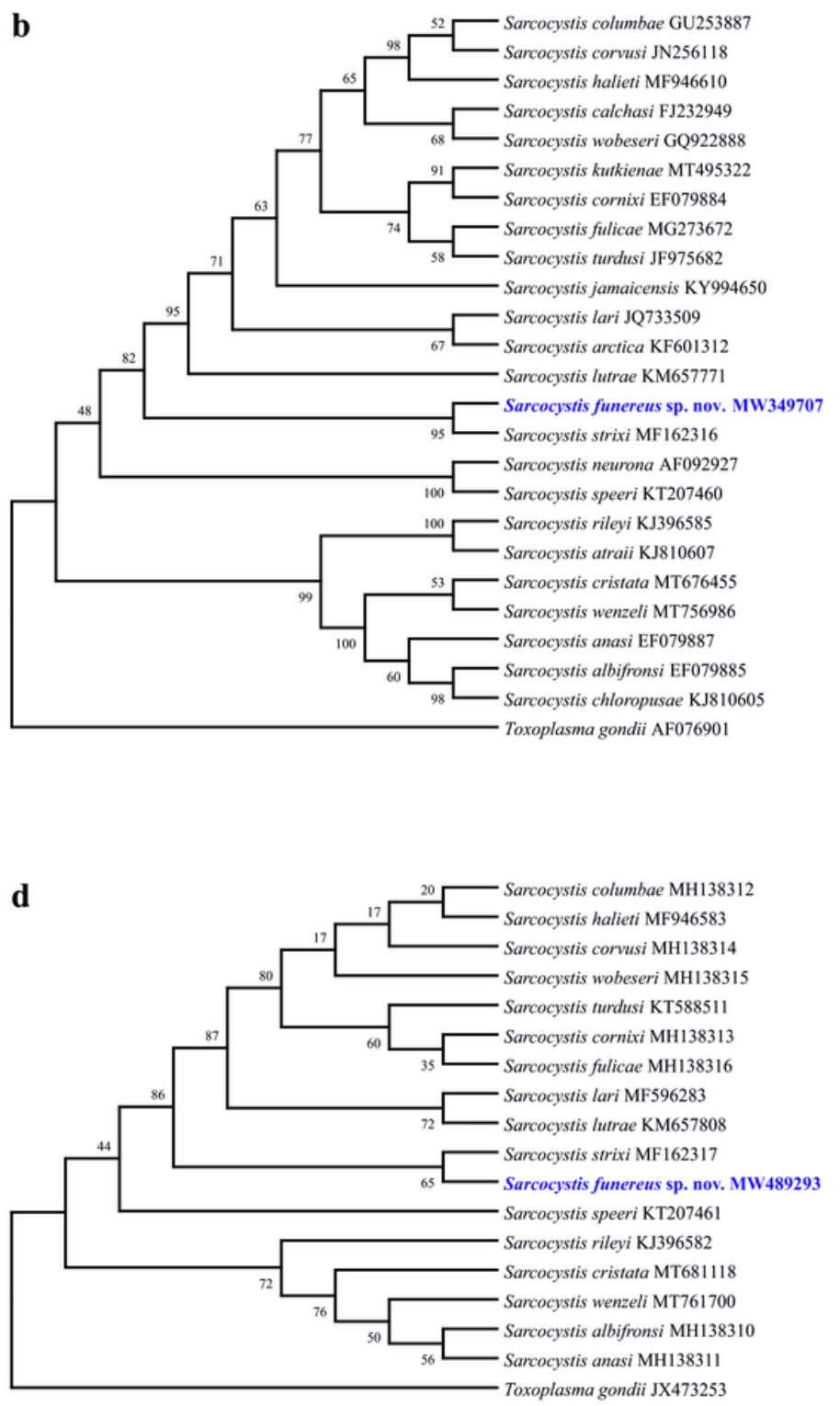

Figure 2

Phylogenetic trees of the species of Sarcocystis from various hosts based on sequences of 18S rRNA (a), $28 \mathrm{~S}$ rRNA (b), ITS1 (c) and cox1 (d) loci. The numbers on phylogenetic trees represent bootstrap values based on 1000 replications. Genbank accession numbers follow Sarcocystis taxa

\section{Supplementary Files}

This is a list of supplementary files associated with this preprint. Click to download.

- Graphicalabstract.png 